\title{
A proposed citizen participation-public trust model in the context of service delivery protests in South African local government
}

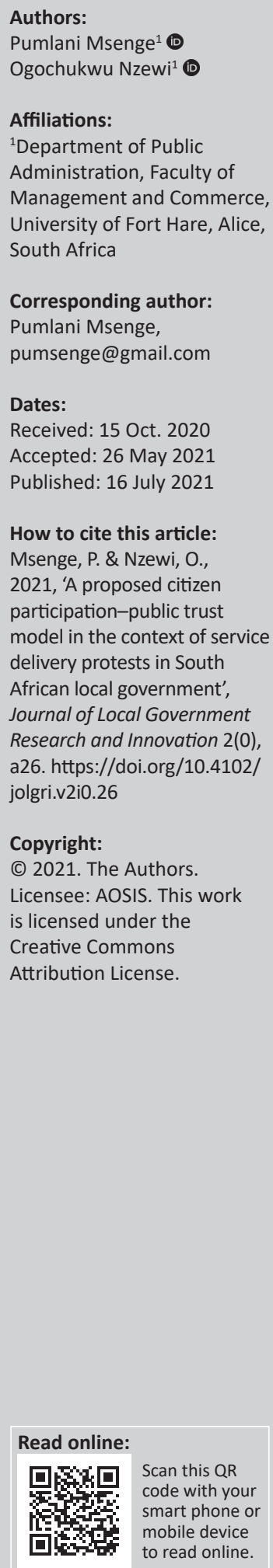

The South African local government context has been marred by persistent citizen protests that continue to jeopardise public administrators' quest for effective service rendering. Such protests have been attributed to the disregard of citizen participation in local government and unresponsive service rendering, amongst other factors. Meaningful citizen participation is seen as a precondition for the establishment of trust between communities and public administrators. This article, delving into the empirical literature, presents a citizen participation and public trust model aimed at minimising service delivery protests in South Africa. It argues that whilst lack of community trust has been lauded as one of the factors that have brewed citizen protests over the years, there is evidence to show that between the core values of procedural justice and public trust, citizen perception of power to influence may be vital to minimise proclivity to protest. The article finds that in addition to the interactional and informational justice components of procedural justice, meaningful citizen participation can be measured as a combination of these justice areas with mechanisms that highlight citizens' positive perceptions of their power to influence decisions. As recommendations, the article argues that indeed lack of community involvement in municipal processes has the potential to break down trust and explode into service delivery protests. However, the article concludes that ensuring meaningful participation in local government decision-making processes, as defined in this article, is a precondition for building community trust and limiting the outbreak of service delivery protests in the local government context.

Keywords: community participation; public trust; service delivery protests; local government; South Africa.

\section{Introduction}

The first democratic elections in 1994 signalled the administrative transformation from a fragmented bureaucratic system to a representative one that sought to champion the priorities of the majority through participatory democracy. The main euphoria behind the attainment of independence was that the new democratic and participatory system would champion the needs and heed the clamours of previously marginalised groups by setting up democratic institutions that would benefit South African citizens equally (Masango, Mfene \& Henna 2013). In order to establish trust between the citizens and government administrators, community participation was lauded as an imperative precondition. The new constitution of 1996 stipulated the need to enforce community participation as a strategy to deal with a plethora of challenges that were facing the marginalised communities, such as unequal distribution of resources, limited access to social services such as health, lack of access to productive resources such as land and capital or credit facilities, and lack of employment opportunities (Naidoo \& Ramphal 2018). Nevertheless, extant literature reveals that post-apartheid history has been marred by local government administration challenges that have seen citizens protesting for better service delivery (Nkomo 2017). The indication here is that the transformation process from a fragmented bureaucratic system of administration to a representative one has not been smooth. The growing disillusionment and community protests over service rendering in the municipal context is evidence of the euphoric despair that has been experienced over the years.

Persistent citizen protests represent growing evidence of a lack of trust, especially in the local government arena. According to Gordon, Roberts and Struwig (2015), transformations in the responsibilities of local municipalities to focus on the developmental roles, such as the eradication of poverty and advancing the well-being of citizens, have not been smooth. It is imperative to note that challenges such as intergovernmental coordination, a political administrative impasse, 
corruption, embezzlement of funds and lack of staff capacity, amongst other factors, have had a devastating impact on the rendering of services in the context of local government (Modise 2017; Sekgala 2016; Lemanski 2017). In this regard, the citizens have demonstrated a lack of trust and have clamoured to have their grievances addressed through violent protests. In this case, Nzewi, Nomarwayi and Bradshaw (2019) argue that the community-based service delivery protests in the South African local government domain may be viewed as community reactions to the decision-making processes of municipal authorities rather than decision-making outcomes.

The local government sphere is regarded as the coal-face of service delivery because of its closer proximity to the communities. As such, local municipalities are expected to have a larger hold on community trust than any other sphere of government. This is imbedded in statutes such as the White Paper on Local Government (1998), which clearly stipulates that local government entities have a crucial responsibility to provide communities with a conducive socio-economic environment in order to improve their well-being. This ordinarily implies a closer bond between communities and local municipalities, where trust towards each other is central (Nzewi et al. 2019). At the heart of a democratic society such as South Africa, the trust of the community in its government, at the national, provincial and local levels, is imperative for national functionality.

Nkomo (2017) purports that protests against unresponsive delivery of services in the South African local government context have become a common phenomenon that has seen escalating confrontation between the South African Police Service (SAPS) and protesters. In such a scenario, an opportunity for constructive engagement between the local administration and the communities is lost, hence the need to establish the communication channels necessary for reengagement. The protests have increased across South Africa because of unfulfilled services that are provided by the municipality. According to the Municipal IQ reports (2020), the numerous organised and violent service delivery protests in the country have dramatically declined as a result of coronavirus disease 2019 (COVID-19) lockdowns across the country. Nevertheless, the period prior to the outbreak of the COVID-19 pandemic was characterised by citizen protests. This is substantiated by the fact that in 2016 alone, the country witnessed an average of 8.73 protests per month, increasing to 9.83 in 2017. This is a clear indication of the mistrust that exists, especially in local municipalities. Statistics also reveal that in 2018, the average number of protests shot up to 17.75 per month, nearly doubling (Nzewi et al. 2019). This pictures a tremendous rise in protests across South Africa, and if they remain unchecked they might lead the economy into bad shape.

It is against this backdrop that the article provides introspection into the subject of citizen participation as a potential ingredient that can be used to establish a conducive partnership between citizens and government administrators and provide amicable forms that will strengthen community trust in local government. This article seeks to contribute knowledge on citizen participation by moving beyond procedural clarifications to highlight it as a critical element to establish trust between communities and local government entities. To this end, the article is grounded in the following objectives:

- to establish the nexus between citizen participation and public trust in the local government context

- to assess the extent to which citizen participation has played a role in the establishment of public trust in South African local government and vice versa.

\section{Research approach}

The relationship between community participation and public trust in the context of service delivery protests in the South African local government arena was evaluated using secondary data, based on desktop analysis. The availability of extensive literature and empirical research informed the choice of this method. As such, the desktop analysis was based on the use of numerous sources, including books, newspapers, journal articles and internet sources, on the outbreak of service delivery protests vis-à-vis community participation and public trust. In order interrogate stances and discourses that are used to explain the study phenomenon, the researchers found desktop analysis to be a powerful tool to achieve the objectives of the article, hence producing a new perspective about the main variables of the study.

\section{Conceptualisation of key terms}

This article is grounded on the relationship that exists between the aspects of citizen participation and public trust. It is important to explore how these variables have been conceptualised in literature and to show the relationship that exists between them in the context of service delivery protests in South Africa.

\section{Citizen participation}

This article is grounded on the notion that community participation in the municipal processes has the potential to spur public trust. According to Madzivhandila and Maloka (2017), community participation is a process that is meant to provide deprived groups a 'voice' to influence municipal decisions. What is presented in their work reflects the need for these groups to have power and authority to have influence on municipal planning and the implementation of development initiatives that have an effect on their wellbeing. In a similar vein, Zanna (2015) posits that the concept of participation seeks to imbed democracy and transform social cohesion between government and citizens, particularly as relates to the provision of quality and sustainable services and goods. The insinuation here is that the aspect of participation moves citizens beyond interactive processes and into the realm of decision-makers. More so, Simonsen and Robbins (2000) also contributed towards the framing of the concept of community participation through asserting that it is the 
process by which local stakeholders such as community members, government institutions, local businesses, community-based organisations and non-governmental organisations work collectively in decision-making to influence development outcomes in a municipal jurisdiction.

Nzewi et al. (2019:10) describe meaningful participation as 'participation that builds trust and assures interactional and informational justice as important elements of community experiences of treatment in local government participation spaces'. In this regard, they developed a model where meaningful community involvement is articulated as participation that seeks to build and strengthen trust and guarantees interactional and informational justice as pivotal fundamentals of communities' experience of treatment in local government 'invited' spaces for participation (Nzewi et al. 2019). These fundamentals are seen as antecedents of meaningful citizen participation, and these may limit communities' tendencies to engage in protests. This is shown in Figure 1.

Whilst Nzewi et al.'s (2019) model is very important in presenting meaningful participation as a nexus between procedural justice and trust, it is silent on the aspect of communities' power and authority to make meaningful decisions. The point of departure is municipal decisions. According to Sibanda and Lues (2019), public participation needs to be an open and accountable process through which communities can exchange opinions and have the power to influence agenda setting and, ultimately, decision-making. In this regard the notion presented here is that providing communities with power and authority is an element of meaningful participation that can play an essential role in limiting the outbreak of citizen protests because it establishes ownership of municipal programmes and projects. This is further elaborated below.

Based on the scholars' insights on community participation, the current study draws some important indicators that appear to be relevant in local government-community participation discourse. These include:

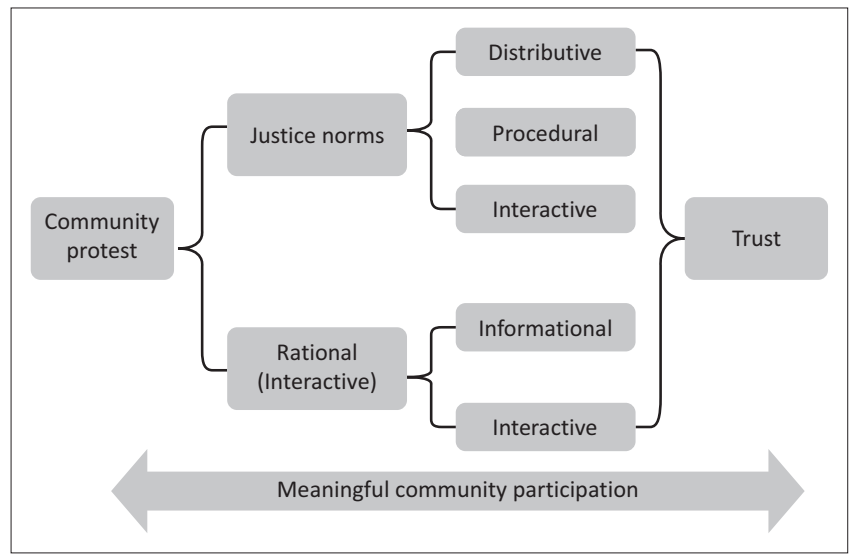

Source: Nzewi, O.I., Nomarwayi, T. \& Bradshaw, G., 2019, 'Between community protest and community trust: The scope of procedural justice in South African participatory local governance', The International Journal of Interdisciplinary Civic and Political Studies 14(1) 1-19. https://doi.org/10.18848/2327-0071/CGP/v14i01/1-19

FIGURE 1: A conceptual framework for meaningful community participation.
1. Power to influence municipal decisions: Providing communities the power and authority to direct resources and influence key decisions in the municipal context is at the heart of meaningful participation. Meschede and Mainka (2020) purport that if citizens have the possibility to co-decide on concrete plans, they have direct influence on local government decisions. This is largely grounded on the rational choice version of exchange theory, which advances the assumption that power dispersal amongst relevant stakeholders is established by the availability of resources from alternative exchange relations in networks (Sibanda \& Lues 2019). It is imperative to note that granting communities power and authority in the municipal context has not been a smooth process for the reason that the power dynamics pose numerous challenges. Massey (2005) argues that community involvement in municipal processes is a product of social relations, which are often conflicting, unequal and a product of conflicting social identities, power asymmetries and value-laden power struggles. Fourie and Reutener (2012) assert that formally established 'invited' spaces such as imbizos, public hearings, ward committees and mayoral roadshows have remained ceremonial and have not given communities power to influence decisions in the South African municipal context. In this regard, power asymmetries that have sidelined communities are seen as pervasive in the brewing conflict between communities and public administrators, leading to citizen protests (Smith \& De Visser 2009). In this case, we argue that the aspect of providing communities with authority over municipal decisions as a core component of community participation has not grasped the attention of many scholars and needs to be emphasised. More so, we argue that the components of meaningful participation (interactional justice and informational justice) presented by Nzewi et al. (2019) are essential in determining the extent to which communities are granted the power to direct resources.

2. Interactional justice: Interactional justice, according to Bies and Moag (1986), includes elements such as honesty in the interactions between local government and communities, politeness, respect in dealing with the people and justifications for municipal decisions. In the South African local government context, the elements of interactional justice are mirrored in the Batho Pele principles, which include: consultation, access, information, service standards, openness and transparency, courtesy and redress and value for money (Nzewi et al. 2019). There is a consensus amongst participatory democracy scholars (Hemson \& Roberts 2008; Holdt et al. 2011; Reutener \& Fourie 2015; Sibanda \& Lues 2019) that these principles are given little consideration in the local government domain, and this explains why citizens are always up in arms against the local government administrators.

3. Informational justice: This aspect focuses on how explanations and information are conveyed to people regarding why certain procedural decisions and outcomes were made (Nzewi et al. 2019). The local strategies are 
complicated by language barriers, lack of capacity for communication and feedback to all community members, and communication breakdown between political and administrative leadership (Paradza, Mokwena \& Richards 2010). As such, informational justice plays a key role in bridging the gap between communities and public administrators.

4. Procedural justice: This aspect of meaningful participation is perceived to be a precondition for bridging the gap between communities and local governments (Nzewi et al. 2019; Sibanda \& Lues 2019). In simple terms, procedural justice is the perception of fairness in the procedures used in decision-making and fair treatment by authorities (Murphy \& Tyler 2008). Leventhal (1980:43) in particular highlighted the fairness of procedures, which he defined as '.. an individual's belief that allocative procedures which satisfy certain criteria are fair and appropriate'. Furthermore, the concept is seen as advancing the aspect of fairness in the rendering of public services (Shafritz \& Russell 2005), adding a social equity perspective in the process. Sibanda and Lues (2019:81) argue that procedural justice 'is premised on distributive justice, support for outcomes, citizen trust and service satisfaction'. In this case, we argue that the concept of procedural justice is at the crux of the establishment of communities' authority and citizen trust.

\section{Public trust}

In the context of local government, trust is seen as an imperative social capital and essential ingredient for good governance and service delivery (MacIntyre et al. 2013). In terms of its conceptualisation, a number of scholars have had difficulties finding a universal definition based on the fact that the concept of trust is a multifaceted, complex and rather ambiguous concept, regarded by many as difficult to define and so to investigate. As such, public trust in government can have different meaning in different contexts. Community trust is defined by MacIntyre et al. (2013:263) as 'believing that a person or organisation will support words with actions'. In a similar vein, Nzewi et al. (2019) assert that community trust is viewed as a local community's belief in the power and legitimacy of local government authorities to take appropriate action to deliver on that community's service delivery expectations as provided for in government policy and local government plans.

Houston and Harding (2014) contend that rather than expectations, trust is based on beliefs. What is expressed in this definition is that expectations imply that we are calculating the probabilities that individuals will pursue particular courses of action. In this regard, trust in government is viewed as referring to the level of confidence citizens have in their government to 'do the right thing', to act appropriately and honestly on behalf of the public (Houston \& Harding 2014). Porumbescu (2015) is of the view that public trust in government is fundamental for the reason that it speaks to the quality of the relationship that exists between citizens and their government. In contrary, low levels of trust among citizens lead to long periods of social, localised, provincial or national actions of protest, violence and destabilisation that can result in destructive consequences for governments and governance in general.

\section{Citizen participatory mechanisms in local government: An overview}

The new democratic era in South Africa sought to introduce a system with a massive engrained focus on participatory democracy grounded in public participation through a myriad of mechanisms (Qwabe \& Mdaka 2011). This is based on the fact that the constitution of 1996 stipulated the need to enforce community participation as a strategy to deal with the plethora of challenges that were facing marginalised communities, such as unequal distribution of resources, limited access to social services such as health, lack of access to productive resources such as land and capital or credit facilities, and lack of employment opportunities (Naidoo \& Ramphal 2018). This saw the enactment of legal statutes such as the Municipal Structures Act (117 of 1998), White Paper on Local Government (1998) and the Municipal Systems Act (32 of 2000), which provided for citizen participation. As such, grassroots structures were set up to achieve this objective. Although community participation has been lauded as a cornerstone for local government administration, the role played by communities in influencing municipal decisions has been under strain.

It is imperative to note that the aspect of participatory local government is imbedded in the integrated development planning (IDP) mechanisms in the South African local government processes. This entails that it is statutorily mandated that the IDP process be participatory and consultative, involving community members in development planning, budgeting and even in the rating of the performance of municipalities in the implementation of IDP mechanisms (Nzewi et al. 2019). Nevertheless, empirical evidence and the extant literature show that the implementation processes that relate to participatory local governance are challenging and complex. It is prudent to note that the area of public engagement in local government processes has been entrenched in the IDP and community-based planning (CBP) processes:

1. Citizen participation in integrated development planning processes: Fourie and Reutener (2012) assert that IDP processes, as legislative criteria that represent the strategic growth plan of a municipality, filled the void of matching community participation and planning with a wider strategic growth context. Integrated development planning is used as a tool to define and prioritise the mission and goals of a municipality over a span of 5 years through participatory processes and budget coordination (Mathebula 2018). A review of the IDP process remains an important prerequisite for municipal strategic planning, which is the first phase in the budget-making process. According to Rambunda and Masenya (2017), in 
South Africa the level of community participation within the municipal planning environment has increased because of IDP implementation.

2. Community-based planning processes: The shift towards developmental local government also emphasised decentralisation processes that were meant to give communities a voice in administrative processes that affect their day-to-day lives and well-being. Reutener (2015) purports that the CBP process:

\begin{abstract}
[E]ntails the active participation of community members, notably those that are commonly referred to as marginalised groups, in managing their own development and that services provided by local government structures are facilitated, coordinated and promoted effectively and responsibly as part of a responsive assertiveness to the community. (p. 209)
\end{abstract}

This participatory mechanism was meant to promote the active involvement of communities through a reflection of community-based plans in the IDP process. According to Sekgala (2016), the ward committee system is one of the structures that can advance CBP within the IDP framework. Reutener (2015) argues that the institutionalisation of the public-based planning system and the IDP component effectively promotes community engagement, offers an organisational structure, formalises contact between the council and the community, and respects diversity.

It is worth pointing out that the implementation of participatory local government has not been smooth for the reason that daunting challenges have been raised. As such the concept of community participation has faced some critics over the years. Fourie and Reutener (2012) argue that there are certain barriers that seem to limit the effective implementation of meaningful public participation in the local government processes. These include, amongst other factors, the non-existence of a participatory culture, political interference and a lack of capacity on the part of community representatives. The established structures and interaction facilitation mechanisms, such as the typical izimbizo (mass gatherings or meetings), ward committees and IDP processes, are created spaces that are mostly symbolic and have not lived up to their expectations of bridging the gap between communities and local government entities. In line with this, Bassett (2016) attests that despite the potential for citizen participation to improve democratic transparency and lead to policies supporting the interests of the disadvantaged, local governments have followed a hierarchical and plutocratic strategy that has given people minimal spaces to control municipal decisions.

To buttress the view presented above, Mofolo (2016) avers that elements of citizen participation such as interactional and informational justice have not fully been prioritised. There is evidence of information deficiency because of the uneven manner with which local municipalities not only implement but also publicise and disseminate information on their participatory initiatives. In line with this, Paradza et al. (2010) assert that the local mechanisms for communication are affected by numerous barriers such as language, lack of capacity for communication and feedback to all community members, and communication breakdown between political and administrative leadership. In this regard, communication breakdown between local government officials and citizens is seen as one of the factors that diminish trust in local government and brew service delivery protests across the country. According to Vermunt and Steensma (2016), when information about service delivery outcomes is missing, vague or untimely, procedural and interactional justice perceptions will serve as proxies for assessing the fairness of outcomes. As such, the notion advanced in this article is that ignorance of such participatory mechanisms and the politics of exclusion have hampered public trust in local government institutions.

\section{Public trust in the local government context}

In the South African context, elements of community-local government engagement such as truthfulness in the communications and interactions, respect, propriety in dealing with people and justifications for decisions are perhaps best reflected in the South African Batho Pele principles of access, courtesy, consultation, service standards, information, openness and transparency, and redress and value for money (Nzewi at al. 2019). These principles have significance for public trust, as they heighten the expectation of participatory governance in local government service delivery. InSouth Africa, society's confidencein transparency, accountability and fairness has plummeted (World Economic Forum 2018), in large part because of disregard of the main elements of meaningful participation, such as interactional and informational justice. Trust in both public institutions has eroded over time. The 2016 Afrobarometer survey revealed that economic meltdown and corruption allegations linked to the Nkandla case made headlines as contributory factors to a dramatic drop in public trust (Mantzaris \& Pillay 2016). The findings of the survey revealed that community trust in the president continues to dwindle and has dropped by almost half since 2011 , from $62 \%$ to $34 \%$, its second-lowest level since the first survey in 2000 (Chingwete 2016:4). This is illustrated in Table 1.

Public confidence in the presidents of South Africa has plummeted since the surveys started with the Afrobarometer in 2000. Trust in President Thabo Mbeki was weak in 2000-2002, then increased in 2004-2006 to an average of $61 \%$. Motlanthe's low level of confidence $(31 \%)$ and high proportion of 'don't know' (26\%) responses are likely to reflect his brief period in office when the survey was conducted. The confidence rates of Zuma reached up to $62 \%$ in 2011 before falling by $28 \%$ (Chingwete 2016). The diminishing level of trust explains why Zuma was ousted before the end of his presidential term, owing to corruption allegations.

Trust issues have had a domino effect on the members of Parliament (MPs), provincial premiers and local government 
TABLE 1: Trust in South Africa's presidents, 2000-2015.

\begin{tabular}{|c|c|c|c|c|c|c|c|c|c|}
\hline \multirow[t]{2}{*}{ Survey } & \multirow[t]{2}{*}{2000} & \multirow[t]{2}{*}{2002} & \multirow[t]{2}{*}{2004} & \multirow[t]{2}{*}{2006} & \multicolumn{3}{|c|}{2008} & \multirow[t]{2}{*}{2011} & \multirow[t]{2}{*}{2015} \\
\hline & & & & & $\begin{array}{l}\text { Trust new President } \\
\text { Motlanthe }\end{array}$ & $\begin{array}{c}\text { Trust ex- President } \\
\text { Mbeki }\end{array}$ & $\begin{array}{c}\text { Trust ANC President } \\
\text { Zuma }\end{array}$ & & \\
\hline President & \multicolumn{4}{|c|}{ Mbeki: June 1999 - Sept 2008} & \multicolumn{3}{|c|}{ Motlanthe: Sept 2008 - May 2009} & \multicolumn{2}{|c|}{ Zuma: May 2009-2015 } \\
\hline Trust 'somewhat' or 'a lot' & $42 \%$ & $37 \%$ & $66 \%$ & $69 \%$ & $31 \%$ & & $43 \%$ & $62 \%$ & $34 \%$ \\
\hline Don't know & $7 \%$ & $4 \%$ & $3 \%$ & $2 \%$ & $26 \%$ & & $5 \%$ & $1 \%$ & $1 \%$ \\
\hline
\end{tabular}

Source: Chingwete, A., 2016, In South Africa, citizens' trust in president, political institutions drops sharply, Afrobarometer Dispatch No. 90, Institute for Justice and Reconcilliation, Afroborometer, Cape Town ANC, African National Congress.

councils, where citizen support has also declined dramatically, making political leaders the least-trusted public officials in the country (Lekalake 2016). In the local government arena, one indicator that has been used to measure trust is the local government election results, which may explore the community's reaction to local government decisions and outcomes that are unfavourable. In this case, the results of the 2016 local government elections perhaps provide some evidence of citizens' trust in how the ruling party (the African National Congress [ANC]) managed local government (Nzewi et al. 2019). Table 2 shows the extent to which the support of the ANC diminished between the years 2000 and 2016.

The data presented in Table 2 reveals that even though the ruling party retained control of the four municipalities, there was a well-documented drastic decline in its support in the 2016 elections. The data also show that Tshwane and Johannesburg metros recorded a 14\% drop, whilst Ekhuruleni and Nelson Mandel Bay metros recorded 13\% and 11\%, respectively.

As compared to other countries, the picture still looks promising in South Africa, but closer scrutiny reveals that trust in government officials and public institutions continues to dwindle. Based on the 2016 local government election results, it can be deduced that whilst the ruling party was able to get $55.65 \%$ support, trust in local government appears to be under strain because citizens' value expectations and rewards over time are not met (Hemson 2010). On trust in local government to deliver services, the South African Social Attitudes Survey reveals some interesting statistics (Hemson 2010). Citizens expressed more trust in the national government than in local government. However, citizens in remote and low-income municipalities tended to have a higher level of trust in local government (up to 67\%) than those in higher-income areas, where local government seems more established (Hemson 2010).

The argument advanced in this article is that citizens' reactions to unresponsive service delivery outcomes can be extreme in communities where participation is perceived to be low. It is imperative to note that the consideration of key aspects of interactional and informational justice is best reflected in the Batho Pele principles, which include access, courtesy, consultation, service standards, information, openness and transparency, and redress and value for money (Lemanski 2017). With reference to community experiences with the application of these principles, an Human Sciences Research Council (HSRC) report from the South African
TABLE 2: Party support in local government elections in key ANC-dominant metros, 2000-2001.

\begin{tabular}{lcccc}
\hline Metro & \multicolumn{4}{c}{ Party support (\%) in the year } \\
\cline { 2 - 5 } & $\mathbf{2 0 0 0}$ & $\mathbf{2 0 0 6}$ & $\mathbf{2 0 1 1}$ & $\mathbf{2 0 1 6}$ \\
\hline Tshwane & 56.30 & 56.35 & 55.32 & 41.22 \\
Johannesburg & 58.90 & 62.29 & 58.56 & 44.55 \\
Ekhuruleni & 56.50 & 61.34 & 61.63 & 48.64 \\
Nelson Mandela Bay & 65.73 & 66.53 & 51.91 & 40.92 \\
\hline
\end{tabular}

Source: Adapted from Independent Electoral Commission (IEC), 2016, Independent Electoral Commission, viewed n.d., from http://www.iec.org.za

Social Attitude survey revealed that local government officials showed very minimal application of the competencies, discretion and attitudes needed to ensure equity and fairness in service delivery as provided for in the Batho Pele principles (Hemson \& Roberts 2008). More so, the poorest areas with the greatest need, such as informal settlements and rural areas, experienced the lowest level of consultation, service standards, openness and transparency, and other Batho Pele principles. In a study by Holdt et al. (2011), factors that relate to neglect, exclusion, force and indifference by local government officials were used as community narratives for taking part in the protests.

The ignorance of informational justice has also been used to explain the widening gap between communities and local government officials, as well as diminishing levels of trust. Nzewi et al. (2019) assert that information constraints continue to menace local municipalities. Mofolo (2016) found a lack of feedback to communities as one of the challenges within local government participatory structures. Other evidence suggests that community perceptions of public participation are positively affected when officials are seen to follow up on key issues (Buccus et al. 2007). Thus, a notable cause of service delivery protests is poor communication between communities and municipal officials. Indeed, when information about service delivery outcomes is missing, vague or untimely, procedural and interactional justice perceptions will serve as proxies for assessing the fairness of outcomes (Vermunt \& Steensma 2016). In this regard, we argue that the elements of meaningful participation play a significant role in determining the levels of trust and the outbreak of protests.

Some of the factors that have exacerbated low levels of trust relate to perceptions regarding poor performance and unethical behaviour (Edelman Trust Barometer 2013). In a similar vein, an Ipsos study in 2012 revealed that $27 \%$ of study participants expressed distrust in local government, citing corruption, lack of transparency and nepotism. According to the Department of Government Communication and Information System (2016), 21\% of the respondents in 
the Ipsos study mentioned officials not fulfilling their promises as the reason for their lack of trust. The point of departure advanced in this study is that flawed community participatory mechanisms have compromised aspects of procedural justice, leading to diminishing trust in local authorities. It is important therefore to show how a lack of trust has degenerated into violent service delivery protests across the country.

\section{Service delivery protests in local government}

Over the years, the local government context has been gripped by violent service delivery protests, and this is evidence of diminishing public trust levels. Service delivery protests are described as 'action through which the residents of an area decide to voice their dissatisfaction or grievances with the manner and scale at which public services are rendered to them' (Shaidi 2013:16). Although various scholars have tried to distinguish between community protests and service delivery protests, these are used interchangeably in this article. It is worth noting that the service delivery protests have been championed to raise communities' concerns over the lack of service rendering, such as the provision of safe and clean water, sanitation facilities and electricity, amongst other services. According to Powell, O'Donovan and De Visser (2015), some of the factors that have brewed violent protests in the local government context include poor maintenance and provision of infrastructure and housing, high service charges, patronage and corruption. A number of studies have been carried out to determine how many service delivery protests occur in South Africa (Table 3).

Extant literature shows that service delivery protests have been on the rise, and unresponsive service delivery has been condemned as the main factor (Masiya, Davids \& Mangayi 2019; Nkomo 2017). According to Municipal IQ (2018), 2018 was already positioned to set a new record, with 42 protests between January and March 2018, and 101 protests measured between April and June alone. This is an average of at least one service delivery protest every 2 days. One of the factors that have been condemned for the service delivery protests brewing in the local government arena is the fact that local government represents a bureaucratic nightmare (Nzewi et al. 2019). This rigid top-down approach is believed to slow down the rendering of services such as water, housing, electricity and sanitation to overcome the legacies of apartheid (Hartley 2014). With the slow pace of service delivery, people will demand more services through protest actions against local authorities.

In addition to unresponsive service delivery, some factors that have heightened the protests include poverty and unemployment, lack of participatory democracy and lack of access to information (Sithole \& Mathonsi 2015). Mamabolo (2015) opines that lack of employment opportunities and high poverty levels are contributory factors towards protests because most people rely on government or their local municipality for better service delivery because of lack of economic opportunities such as proper employment and food security. In this regard, the failure by municipalities to provide basic services compels these individuals to protest. Mathebula (2018) shares the same sentiment that a major factor in the protests is poverty, with its accompanying socioeconomic conditions and unemployment. Lastly, Chikulo (2016) states that there are claims that the protests against poor service delivery are strengthened by the growing inequality and poverty in South African societies.

According to Modise (2017), ignorance about participatory democracy has limited the interactions between communities and public officials. It is worth noting that individuals usually demonstrate their disillusionment with exclusion from decision-making processes through protests (Brooks 2017). The concept of participatory democracy is a great challenge for democratic South Africa because citizens have inadequate knowledge about the administrative operations of local municipalities. The service delivery protests are a clear indication that participatory democracy is a great challenge in democratic South Africa, and as a result poor public participation leads to underdevelopment of local government (Modise 2017). This means that interactional justice has not been fully prioritised, and this has strained the relationship between communities and local government officials; the protests are a product of this strained relationship.

Chigwata et al. (2017) asserts the lack of consideration of informational justice has been used to explain the occurrence of community protests in South Africa. The right to access information is one of the fundamental rights enshrined in the constitution of the Republic of South Africa (1996). Furthermore, the Batho Pele principles put more emphasis on information

TABLE 3: Protest numbers by various organisations, 2012-2017.

\begin{tabular}{|c|c|c|c|c|c|c|c|}
\hline \multirow[t]{2}{*}{ Organisation } & \multirow[t]{2}{*}{ Focus area } & \multicolumn{6}{|c|}{ Number of protests in the year } \\
\hline & & 2012 & 2013 & 2014 & 2015 & 2016 & 2017 \\
\hline $\begin{array}{l}\text { Centre for Social Change, University } \\
\text { of Johannesburg (CSC) }\end{array}$ & All 'community' protests & 471 & 322 & 375 & 343 & 377 & 375 \\
\hline Municipal IQ & Protests against local government & 173 & 155 & 191 & 164 & 137 & 152 \\
\hline $\begin{array}{l}\text { Civic Protest Barometer (CPB), } \\
\text { University of the Western Cape }\end{array}$ & 'Civil' protests against local government & 150 & 140 & 176 & 126 & $\begin{array}{c}\text { Not } \\
\text { available }\end{array}$ & $\begin{array}{c}\text { Not } \\
\text { available }\end{array}$ \\
\hline $\begin{array}{l}\text { Armed Conflict Location and Event } \\
\text { Data Project (ACLED) }\end{array}$ & $\begin{array}{l}\text { 'Political violence and protest', including political } \\
\text { mass events such as campaign rallies }\end{array}$ & 1060 & 1045 & 1084 & 1487 & 1418 & 1026 \\
\hline $\begin{array}{l}\text { Social Conflict Analysis Database } \\
\text { (SCAD) }\end{array}$ & 'Social and political disorder' & 825 & 617 & 757 & 938 & 979 & Not available \\
\hline
\end{tabular}

Source: Adapted from Lancaster, L., 2018, 'Unpacking discontent: Where and why protest happens in South Africa', South African Crime Quarterly 64. https://doi.org/10.17159/2413-3108/2018/v0n64a3031 
access as a right that needs consideration in municipal governance (Mathebula 2017). According to Morudu (2017), service delivery protests in rural areas make clear how a lack of access to information often leads to the rapid spread of rumours of favouritism, corruption and mismanagement. Despite the media and other communication tools, communication is still a pandemic issue that needs to be resolved and improved.

\section{Exploring the nexus between community participation and public trust in the context of service delivery protests}

The relationship between the main variables of the article needs to be explored to show how elements that contribute to them interrelate. A number of researchers have found that public trust is also one of a variety of factors that can influence the effectiveness of efforts to mobilise citizens. An analysis of the trust levels in various actors may help us understand to what extent citizen mobilisation may be achieved and thus inform project strategy (Oxfam 2019). However, the link between trust and citizen engagement is complex. According to Muller (2013), higher community levels of trust in government institutions are associated with higher levels of citizen participation. In contrast, lower community levels of trust in government institutions have the potential to induce disillusionment and apathy, where citizens refrain from voicing their concerns towards duty bearers at all (Muller 2013). According to Chu and Shen (2017), this kind of disengagement between government institutions can contribute towards protest behaviour by citizens. Based on the exploration of the relationship amongst the study variables, the conceptual framework presented in Figure 2 explores the notion that the enhancement of meaningful community participation is key for attaining fairness in local government processes, which may in turn influence the aspect of trust. Conversely, disregard of the main principles of active participation may have a negative effect on procedural justice, diminishing the levels of trust in the processes.

The assertion presented in this article is that communities' power to influence municipal decisions is less emphasised in the scholarly fraternity, and it is at the crux of the establishment of public trust. We argue in this article that the

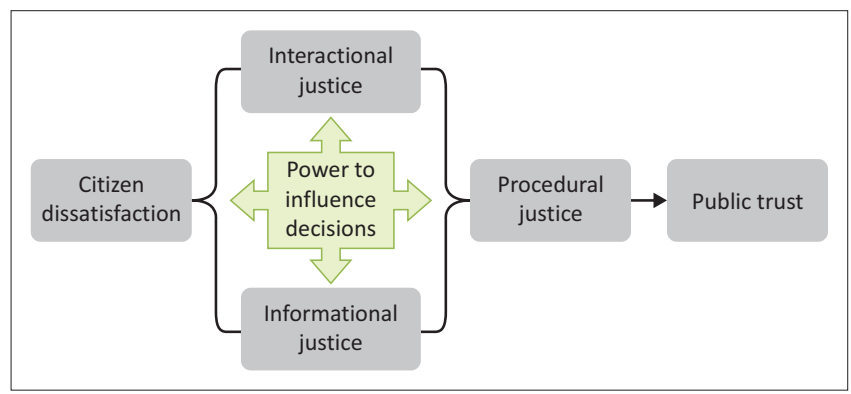

Source: Msenge, P. \& Nzewi, O., 2020, An Assessment of the Contribution of Community participation on public trust in local government: A case of King Sabatha Dalindyebo Local Municipality, Dissertation, forthcoming, University of Fort Hare, Fort Hare

FIGURE 2: Citizen participation-public trust model. levels of engagement between communities and public officials must emphasise the need to provide communities a role to play in determining where resources are to be allocated. The argument presented in this article is that the public's perception of their power to influence the process is a precondition to meaningful citizen participation, which minimises disillusionment in local government participatory processes. Once this aspect is achieved, trust between local government institutions and communities is established. Marques et al. (2015) found that perceptions of public trust in government are greater in cases where people are involved in the municipal processes.

Granted that fewer studies exist on community participation and trust in local government, one study by Kim and Lee (2012) found that perceptions of effective participation enhanced satisfaction with quality of services. Their study also found a positive association between government transparency and trust in government. The assertion presented in the proposed framework above is that meaningful community participation plays a significant role in enhancing public trust in government. Kim (2016) asserts that once these elements are realised, trust in local government is enhanced. On one hand, a break in trust resulting from perceptions of unfair procedures can elicit strong adverse reactions. On the other hand, trust can be built by working to increase perceptions of fair outcomes and procedures (Nzewi et al. 2019). In this regard, the nexus between meaningful participation and trust is essential in understanding how communities react to local government decision-making. This also suggests that understanding the dynamics of public participation must include sensitivities to informational and interactional justice in acknowledging communities' roles, dignity, ownership and values in building trust towards favourable outcomes (Nzewi at al. 2019).

\section{Conclusion}

Citizen participation is a vital approach that can be used by public sector institutions in their quest to improve public trust in local government and quell service delivery protests. Evidence from practice reflects that a number of municipalities across the country have encountered service delivery protests that have degenerated into violence. Even though the concept of community participation remains entrenched in a number of statutory instruments, it has not yet lived up to expectations in terms of bridging the gap between communities and public officials. Less consideration of community participation elements such as interactional and informational justice has dealt a heavy blow to public trust. The article finds that meaningful citizen participation is an ingredient necessary for positive local community reactions to service delivery outcomes. Conversely, a lack of community involvement in municipal processes such as planning, budgeting and the implementation of programmes and projects has the potential to break down trust and explode into service delivery protests. The article concludes that ensuring meaningful participation in local government 
decision-making processes is a precondition for building community trust and limiting the outbreak of service delivery protests in the local government context.

\section{Acknowledgements} Competing interests

The authors declare that no competing interests exist.

\section{Authors' contributions}

Both authors have contributed equally to this work.

\section{Ethical considerations}

This article followed all ethical standards for a research without direct contact with human or animal subjects.

\section{Funding information}

This research received no specific grant from any funding agency in the public, commercial or not-for-profit sectors.

\section{Data availability}

Data sharing is not applicable to this article as no new data were created or analysed in this study.

\section{Disclaimer}

The views and opinions expressed in this article are those of the authors and do not necessarily reflect the official policy or position of any affiliated agency of the authors.

\section{References}

Bassett, C., 2016, 'An alternative to democratic exclusion? The case for participatory local budgeting in South Africa', Journal of Contemporary African Studies 34(2), 282-299. https://doi.org/10.1080/02589001.2016.1202584

Bies, R.J. \& Moag, J., 1986, 'Interactional justice: Communication criteria of fairness', in R.J. Lewicki, B.H. Sheppard \& M.H. Bazerman (eds.), Research on negotiation in organizations, vol. 1, pp. 43-55, JAl Press, Greenwich.

Brooks, H., 2017, 'The mass movement and public policy: Discourse of participatory democracy in post-1994 South Africa', Journal of Modern Africa Studies 55(1), 105-127. https://doi.org/10.1017/S0022278X16000793

Buccus, I., Hemson, D., Hicks, J. \& Piper, L., 2007, Participation and Local Governance, The Centre for Public Participation, Human Sciences Research Council, University of KwaZulu-Natal, 18-19, viewed n.d., from http://www.cpp.org.za/docs/ reports/2007/Ig-report0507.pdf.

Chigwata, T.C., Powell, D.M. \& O'Donovan, M., 2017, Civic protests and local government in South Africa: The civic protests barometer 2007-2016, Working Paper Series No. 2, ACSL, Dullah Omar Institute, Cape Town, viewed 16 February 2017, from https://dullahomarinstitute.org.za/acsl/civic-protests-barometer_2016.pdf.

Chikulo, B.C., 2016, 'The smoke that calls: A review of service delivery protests in South Africa 2005-2014', Journal of Human Ecology 55(2), 51-60. https://doi.org /10.1080/09709274.2016.11907009

Chingwete, A., 2016, In South Africa, citizens' trust in president, political institutions drops sharply, Afrobarometer Dispatch No. 90, Institute for Justice and Reconcilliation, Afroborometer, Cape Town

Chu, Y. \& Shen, C., 2017, 'Civic engagement and institutional trust among South Africans', The Journal of Sociology \& Social Welfare 44(3), Article 3.

Edelman Trust Barometer, 2013, 2013 Edelman Trust barometer, viewed 13 January 2019, from www.edelman.com/ research/2013-edelman-trust-barometer.

Fourie, D. \& Reutener, M., 2012, 'Revisiting participatory budgeting as a potential service delivery catalyst', African Journal of Public Affairs 5(2), 80-92.

Gordon, S.L., Roberts, B.J. \& Struwig, J., 2015, Trusting the coalface: public trust in South African local government and the millennium development goals, Human Sciences Research Council, pp. 60-80, viewed 15 January 2015, from http:// ecommons.hsrc.ac.za/handle/20.500.11910/1841.
Hartley, R., 2014, Ragged glory: The rainbow nation in black and white, Jonathan Ball Publishers, Johannesburg.

Hemson, D., 2010, '“Winters of discontent? Attitudes towards service delivery”', in B. Roberts, M.W. Kivilu \& Y.D. Davids (eds.), South African social attitudes, 2nd report: Reflections on the age of hope, pp. 107-127, HSRC, Cape Town.

Hemson, D. \& Roberts, B., 2008, Batho Pele: Season of discontent, 4th edn., Vol. 6 , HSRC, Cape Town, viewed 04 November 2008, from http://www.hsrc.ac.za/ uploads/pageContent/1607/BathoPele.pdf.

Holdt, K., Langa, M., Molapo, S., Mogapi, N., Ngubeni, K., Dlamini, J. et al., 2011, The smoke that calls: Insurgent citizenship, collective violence and the struggle for a place in the New South Africa: Eight case studies of community protest and xenophobic violence, Centre for the Study of Violence and Reconciliation, Johannesburg.

Houston, D.J. \& Harding, L.H., 2014, 'Public trust in government administrators explaining citizen perceptions of trustworthiness and competence', Public Integrity 16(1), 53-76. https://doi.org/10.2753/PIN1099-9922160103

Independent Electoral Commission (IEC), 2016, Independent Electoral Commission, viewed n.d., from http://www.iec.org.za.

Kim, S., 2016, Public trust in Government in China and South Korea: Implications for building community resilience, Public Administration, Chin.

Kim, S. \& Jooho, L., 2012, 'E-participation, transparency, and trust in local government', Public Administration Review 72(6), 819-828. http://doi.org/10.1111/j.15406210.2012.02593.x

Lancaster, L., 2018, 'Unpacking discontent: Where and why protest happens in South Africa', South African Crime Quarterly 64. https://doi.org/10.17159/2413-3108/ 2018/v0n64a3031

Lekalake, R., 2016, South Africans generally tolerant but report racial discrimination by employers and courts, Afrobarometer Dispatch No. 84, viewed 20 April 2016, from http://afrobarometer.org/sites/default/files/publications/Dispatches/ab_r6_ from http://afrobarometer.org/sites/default/
dispatchno84-south-africa-discrimination.pdf.

Lemanski, C., 2017, 'Unequal citizenship in unequal cities: Participatory urban governance in contemporary South Africa', International Development Planning Review 39(1), 15-35. https://doi.org/10.3828/idpr.2017.2

Leventhal, G.S., 1980, 'What should be done with equity theory?', in K.J. Gergen, M.S.Greenberg \& R.H. Willis (eds.), Social exchange: Advances in theory and research, pp. 27-55, Springer, Boston, MA.

MacIntyre, L.M., Rankin, S., Pinderhughes, H., Waters, C.M., Schell, E. \& Fiedler, R. 2013, 'Socially disempowered women as the key to addressing change in Malawi: How do they do it?', Health Care for Women International 34, 103-121. https:// doi.org/10.1080/07399332.2011.630116

Madzivhandila, T.S. \& Maloka, C.M., 2017, 'Community participation in local government planning processes: A paramount step towards a successful service delivery', Mediterranean Journal of Social Sciences 5(16), 652-657.

Mamabolo, M.A., 2015, 'Drivers of community xenophobic attacks in South Africa: Poverty and unemployment', TD: The Journal for Transdisciplinary Research in Poverty and unemployment', TD: The Journal for Transdisciplinary
Southern Africa 11(4), 143-150. https://doi.org/10.4102/td.v11i4.49

Mantzaris, E. \& Pillay, P., 2016, Public trust and good governance: A South African case study, Accerus- Anti Corruption Centre for Education and Research, Stellenbosch study, Accerus- Anti Corr
University, Stellenbosch.

Marques, S., Lima, M.L., Moreira, S. \& Reis, J., 2015, 'Local identity as an amplifier: Procedural justice, local identity and attitudes towards new dam projects', Journal of Environmental Psychology 44, 63-73. https://doi.org/10.1016/j.jenvp.2015.09.007

Masango, R., Mfene, P.N. \& Henna, T., 2013, An analysis of factors that negatively affect the performance of ward committees in the Buffalo City Municipality, Political Science, Africa Insight.

Masiya, T., Davids, Y. \& Mangai, M.S., 2019, 'Assessing service delivery: Public perception of municipal service delivery in South Africa', Theoretical and Empirical Researches in Urban Management 14(2), 20-40.

Massey, D., 2005, For space, Sage, London.

Mathebula, N.E., 2017, The role of integrated development plans in municipal administration, planning and delivery as vehicles to turn electoral aspirations into realities, Batalea Publishers (Pty) Ltd., Polokwane.

Mathebula, N.E., 2018, 'Integrated development plan implementation and the enhancement of service delivery', Conference proceedings, 3rd IPADA Stellenbosch University, Saldanha Bay, 04-06 July 2018.

Meschede, C. \& Mainka, A., 2020, 'Including citizens participation formats for drafting and implementing local sustainable development strategies', Urban Science 4(1) 13. https://doi.org/10.3390/urbansci4010013

Modise, L.J. 2017, 'The notion of participatory democracy in relation to local ward committees: The distribution of power', In die Skrifflig 51(1), 1-8. https://doi. org/10.4102/ids.v51i1.2248

Mofolo, M.A., 2016, 'Intergovernmental relations system for public participation in the local sphere of government', Journal of Public Administration 52(1), 230-245, the local sphere of government', Journal of Public Administration 52(1), 230-245,
viewed 01 June 2016, from https://journals.co.za/content/jpad/51/2/EJC194415.

Morudu, H.D., 2017, 'Service delivery protests in South African municipalities: An exploration using principal component regression and 2013 data', Cogent Social Sciences 3(1), 1329106. https://doi.org/10.1080/23311886.2017.1329106

Msenge, P. \& Nzewi, O., 2020, An Assessment of the Contribution of Community participation on public trust in local government: A case of King Sabatha Dalindyebo Local Municipality, Dissertation, forthcoming, University of Fort Hare, Fort Hare.

Muller, J., 2013, Mechanisms of Trust: News Media in Democratic and Authoritarian Regimes, Campus Verlag, Frankfurt.

Municipal IQ, 2018, First quarter protests for 2018 show consistent trends with previous years: Press release, viewed n.d., from http://municipaliq.co.za/ publications/press/201804061149381399.doc. 
Municipal IQ, 2020, Municipal Data and Intelligence: A downward dip seen in 2020 service delivery protests - not necessarily an endorsement of municipalities: For immediate release, viewed 15 Januuary 2021, from www. municipalities: For

Murphy, K. \& Tyler, T., 2008, 'Procedural justice and compliance behaviour: The mediating role of emotions', European Journal of Social Psychology 38, 652-668. https://doi.org/10.1002/ejsp.502

Naidoo, C. \& Ramphal, R.R., 2018, 'The factors that affect public participation for effective municipal service delivery: A case of ward committees', South African Journal of Industrial Engineering 29(4), 82-93. https://doi.org/10.7166/29-41948

Nkomo, S., 2017, Public service delivery in South Africa: Councillors and citizens critical links in overcoming persistent inequalities, Afrobarometer Policy Paper. No. 42, Africa Portal, Johannesburg.

Nzewi, O.I., Nomarwayi, T. \& Bradshaw, G., 2019, 'Between community protest and community trust: The scope of procedural justice in South African participatory
local governance', The International Journal of Interdisciplinary Civic and Political Studies 14(1), 1-19. https://doi.org/10.18848/2327-0071/CGP/v14i01/1-19

Oxfam, 2019, Trust and Citizen Action: Theory and evidence from 14 projects, Oxfam, London, viewed n.d. from www.oxfam.org.uk

Paradza, G., Mokwena, L. \& Richards, R., 2010, Assessing the role of councillors in service delivery at local government level in South Africa, Research Report 125 Centre for Policy Studies, Johannesburg.

Porumbescu, G.A., 2015, 'Using transparency to enhance responsiveness and trust in local government: Can it work?', State and Local Government Review 47(3), 205-213. https://doi.org/10.1177/0160323X15599427

Powell, D.M., O’Donovan, M. \& De Visser, J., 2015, Technical note: Civic protests barometer, Dullah Omar Institute, February 19, viewed 09 February 2015, from https://dullahomarinstitute.org.za/acsl/technical-note_civic-protestsbarometer_2016.pdf/@@download/file/Technical\%20Note_Civic\%20 Protests\%20Barometer_2016.pdf.

Qwabe, B. \& Mdaka, P., 2011, Are Ward Committees the voice of communities? viewed 16 April 2018, from http://ggln.org.za/media/k2/attachments/SoLG.2011 Idasa.pdf.
Rambunda, R. \& Masenya, M.J., 2017, 'Augment of gender equity through IDP processes: A strategy of service delivery in a democratic South Africa', paper presented at the 2 nd Annual International Conference on Public Administration and Development Alternatives, 26-28 July 2017, Tlotlo Hotel, Gaborone.

Reutener, M. \& Fourie, D., 2015, 'The role of civic participation in the South African budgeting process', Public and Municipal Finance 4(3), 7-15.

Reutener, M., 2015, The Role of Civic Participation in the South African Budgeting Process, University of Pretoria, Pretoria.

Sekgala, M.P., 2016, 'The role of traditional leaders in local governance: A case study of Limpopo', Unpublished M.A. dissertation, University of the Western Cape, Cape Town.

Shafritz, J.M. \& Russell, E.W., 2005, Introducing public administration, 4th edn., Pearson Longman, New York.

Shaidi, E.W., 2013, 'Investigation into causes of service delivery protests in municipalities: A case study of Nelson Mandela Bay Municipality', Unpublished doctoral thesis, Port Elizabeth, Nelson Mandela Metropolitan University, viewed 02 August 2019, from https://core.ac.uk/download/pdf/145049943.pdf.

Sibanda, M.M.M. \& Lues, L., 2019, 'Public participation in integrated development planning: A case of the Buffalo City Metropolitan Municipality', Administratio Publica 27(1), 79-93.

Simonsen, W. \& Robbins, M., 2000, Citizen participation in resource allocation, Taylor \& Francis, New York, NY.

Sithole, S.L. \& Mathonsi, N.S., 2015, 'Local governance service delivery issues during apartheid and post-apartheid South Africa', Africa's Public Service Delivery and Performance Review 3(3), 5-30. https://doi.org/10.4102/apsdpr.v3i3.87

Smith, T. \& De Visser, J., 2009, Are ward committees working? Insights from six case studies, Community Law Centre, University of Western Cape, Bellville.

Vermunt, R. \& Steensma, H., 2016, 'Procedural justice', in K. Sabag \& M. Schmitt (eds.) Handbook of social justice theory and research, pp. 219-236, Springer, New York, NY.

World Economic Forum, 2018, How to rebuild Trust and Integrity in South Africa, Business Unity South Africa, Sandton, Johannesburg.

Zanna, A.S., 2015, Citizen Participation in Local Governance and Sustainability of Programmes, Global Journalist Inc, Maiduguri. 